\title{
Yoga and Physiotherapy: Therapies Which Complement Each Other
}

\author{
Shirley Telles*, Ram Kumar Gupta and Acharya Balkrishna \\ Patanjali Yogpeeth,Patanjali Research Foundation, India \\ Submission: April 22, 2017; Published: May 02, 2017 \\ *Corresponding author: Shirley Telles, Director, Patanjali Research Foundation, India, Email: shirleytelles@gmail.com
}

\section{Commentary}

Yoga is an Indian science and a way of life which includes physical postures, voluntarily regulated breathing, meditation, certain philosophical principles and recommendations for living in tune with the laws of nature [1]. While yoga was originally intended for spiritual advancement there is a growing interest in applying yoga for therapy and rehabilitation [2]. Rehabilitation includes helping seniors increase their ability to balance and prevent falls [3] as well to improve their gait. Yoga practice can also help persons regain mobility after cerebrovascular accidents culminating in stroke and hemiplegia [4]. In certain cases where the outcome of a disease is early mortality, as in Duchenne's muscular dystrophy, the practice of yoga can improve the quality of life of the patient significantly [5].

Physiotherapy is a science-based profession and takes a 'whole person' approach to health and wellbeing, which includes the patient's general lifestyle (http://www.csp. org.uk/your-health/what-physiotherapy). At the base is the patient's involvement in their own care, through education, awareness, empowerment and participation in their treatment. Physiotherapists help people affected by injury, illness or disability through movement and exercise, manual therapy, education and advice. Physiotherapists maintain health for people of all ages, helping patients to manage pain and prevent disease.The disciplinehelps to encourage development and facilitate recovery, enabling people to stay in work while helping them to remain independent for as long as possible. Hence it is apparent that yoga and physiotherapy both empower an individual to regain health and wellbeing through an all-systems approach to hence improve all aspects of health.

In the ancient yoga texts the importance of the breath is emphasized; this includes diaphragmatic breathing, inhalation and exhalation in a ratio of 1:2 as well as well awareness of the breath. Several of the benefits of yoga in healing, including correction of autonomic imbalance [6] and of motor functions
[7] are attributed to the benefits related to breathing in the correct way, specifoied by yoga texts. In physiotherapy there is also adequate emphasis on breathing; placing adequate importance on breath awareness can help augment the benefits of physiotherapy. Awareness is an integral part of yoga. It is mentioned in the yoga texts and Mindfulness is further emphasized in Buddhist teachings. Awareness helps a patient to actively participate in their healing. Hence as a physiotherapist and patient interact together for healing the patient should remain in a state of 'body awareness' to be more sensitive to interoceptive signals. This would facilitate healing [8].

This brief write-up is intended to suggest how concepts from yoga can be used to augment the multiple benefits of physiotherapy in healing.

\section{References}

1. Tamini IK (1986) The science of Yoga. The Theosophical Publishing House USA.

2. Khalsa SBS, Cohen L, McCall T, Telles S (2016) Principles and Practice of Yoga in Health Care. Pencaitland, Handspring Publishing Limited, UK, pp. 566.

3. Krishnamurthy M, Telles S (2007) Effects of Yoga and an Ayurveda preparation on gait, balance and mobility in older persons. Med Sci Monit 13(12): LE19-LE20.

4. Bastille J, Gill-Body KM (2004) A yoga-based exercise program for people with chronic poststroke hemiparesis. Phys Ther 84(1): 33-48.

5. Telles S, Balkrishna, Maharana K (2011) Effect of Yoga and Ayurveda on Duchenne Muscular Dystrophy. Indian J Palliat Care 17(2): 169-170.

6. Telles S, Sharma SK, Balkrishna A (2014) Blood Pressure and Heart Rate Variability during Yoga-Based Alternate Nostril Breathing Practice and Breath Awareness. Med Sci Monit Basic Res 20: 184-193.

7. Telles S, Naveen KV, Balkrishna A, Kumar S (2010) Short term health impact of a yoga and diet change program on obesity. Med Sci Monit 16(1): CR35-CR40.

8. CSP (2013) What is physiotherapy? Chartered Society of Physiotherapy, UK. 


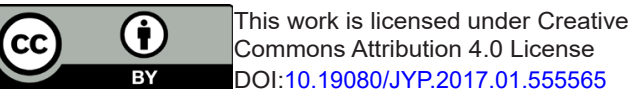

Your next submission with Juniper Publishers will reach you the below assets

- Quality Editorial service

- Swift Peer Review

- Reprints availability

- E-prints Service

- Manuscript Podcast for convenient understanding

- Global attainment for your research

- Manuscript accessibility in different formats ( Pdf, E-pub, Full Text, Audio)

- Unceasing customer service

Track the below URL for one-step submission https://juniperpublishers.com/online-submission.php 